GOSPODARKA SUROWCAMI MINERALNYMI - MINERAL RESOURCES MANAGEMENT

201

Volume 31

Issue 3

Pages 25-44

DOI 10.1515/gospo-2015-0025

\title{
Znaczenie i rola standardu JORC jako podstawy bankowego studium wykonalności projektów górniczych dla oceny rentowności projektu
}

\section{Wprowadzenie}

W związku z zaprzestaniem realizacji szeroko zakrojonych prac poszukiwawczych i poszukiwawczo-rozpoznawczych $\mathrm{w}$ Polsce finansowanych $\mathrm{z}$ budżetu państwa, projekty górnicze mające na celu udokumentowanie i/lub zagospodarowanie nowych zasobów złóż kopalin praktycznie realizowane są jedynie przez koncerny mineralne lub firmy geologiczne (Nieć i in. 2014). Decyzje o rozpoczęciu inwestycji w zakresie poszukiwania, rozpoznania, zagospodarowania, a następnie wydobywania kopaliny ze złoża wymagają relatywnie dużego początkowego zaangażowania kapitałowego, a korzyści ekonomiczne z projektu generowane są zwykle po 5-10 latach od momentu udokumentowania złoża (Szamałek 2007). Poszukiwanie kapitału inwestycyjnego na realizację projektu surowcowego staje się w Polsce coraz szerszą działalnością stymulowaną przez kilka czynników, a wśród nich:

- wprowadzanie do Polski przez zagraniczne przedsiębiorstwa ich ładu korporacyjnego oraz technologii postępowania,

\footnotetext{
* Prof. dr hab., Państwowy Instytut Geologiczny-Państwowy Instytut Badawczy, Zakład Informacji o Złożach i Obszarach Górniczych, Warszawa; e-mail: krzysztof.szamalek@pgi.gov.pl

** Dr hab., Wydział Geologii Uniwersytet Warszawski, Zakład Geologii Złożowej i Gospodarczej, Warszawa; e-mail: jan.wierchowiec@uw.edu.pl
} 
- poszukiwanie przez polskie podmioty środków kapitałowych na rynkach zewnętrznych i zetknięcie się z wymaganiami obowiązującymi w bankach, funduszach inwestycyjnych, funduszach ryzyka typu venture capital,

- globalizację i koncentrację działań koncernów surowcowych,

- transfer know how i doświadczenia zagranicznych podmiotów surowcowych do polskiego przemysłu surowców mineralnych.

Technologia poszukiwania środków finansowych wymaga od przedsiębiorcy górniczego działań opartych na akceptowanych międzynarodowych standardach. Przed kilku laty zatem pojawiła się w Polsce potrzeba przygotowywania dokumentacji zasobowej zgodnej z międzynarodowymi wymaganiami; najczęściej stosowanym standardem jest JORC Code (JORC 2012). Autorzy uczestniczyli w pracach zespołów przygotowujących raporty zasobowe zarówno jako autorzy (Wierchowiec i in. 2013), jak i tzw. Competent person (Mineral expert's report 2012; KHW 2014). W 2014 roku próbę i intensywne starania o pozyskanie funduszy w formie euroobligacji podjął Katowicki Holding Węglowy (KHW 2014). W przygotowaniu niezbędnej dokumentacji i aplikacji na potrzeby emisji euroobligacji wskazana została potrzeba uwzględnienia przez KHW procedury obliczania zasobów węgla kamiennego zgodnej z JORC Code.

Stopień ryzyka niepowodzenia projektu górniczego zmienia się wraz z rozwojem jego zaawansowania. W realizacji (cyklu życia) projektu górniczego, wyróżnia się zwykle pięć faz:

1) poszukiwawczo-rozpoznawcza,

2) koncepcyjno-studialna,

3) zagospodarowania złoża (budowy zakładu górniczego),

4) eksploatacji,

5) likwidacji zakładu górniczego (Nelson 2011; Wirth 2011).

Każda z przedstawionych powyżej faz wymaga odpowiednich nakładów. Prace poszukiwawczo-rozpoznawcze są etapem wstępnym, w którym nakłady inwestycyjne stanowią zazwyczaj od kilku do $15 \%$ wartości całego projektu, lecz cechuje go najwyższy poziom ryzyka, ponieważ nie ma nigdy pewności, że prace poszukiwaczo-rozpoznawcze doprowadzą do udokumentowania złoża (Szamałek 2007).

W przypadku pozytywnego wyniku fazy poszukiwawczo-rozpoznawczej, w etapie drugim (faza koncepcyjno-studialna) rozpatrywane są różne warianty zagospodarowania złoża. Wykonuje się zwykle trzyetapowe opracowanie techniczne - studium wykonalności projektu (ang. Scoping study, Preliminary feasibility study, Bankable feasibility study), mające na celu przygotowanie optymalnej koncepcji zagospodarowania złoża (Whittle i in. 2007; Bullock 2011a, b). Kolejno na etapie budowy zakładu górniczego, tj. fazy zagospodarowania złoża, poziom ryzyka inwestycji ulega pewnemu ograniczeniu, natomiast wydatki kapitałowe są najwyższe. $Z$ kolei faza - eksploatacja złoża, jest kluczowa z punktu widzenia efektu finansowego projektu górniczego; w fazie tej projekt generuje przychody ze sprzedaży kopaliny, surowca mineralnego lub produktu.

W realiach gospodarki rynkowej projekty górnicze zwykle nie są finansowane ze środków własnych. Najpopularniejszą formą pozyskiwania kapitału dla realizacji projektu gór- 
niczego jest tzw. finansowanie długiem (Noakes i Lanz 1993; Scott i Whateley 2006; Park i Nelson 2013). Jednakże zagadnienie źródeł finansowania projektu surowcowego należy rozważać w zależności od etapu rozwoju projektu; dotyczy to zwłaszcza etapu poszukiwania oraz projektu w fazie udostępniania złoża (Wirth 2011).

Najczęściej finansowanie długiem odbywa się poprzez kredyty z instytucji bankowych. Banki udzielają kredytów (zgodnie ze swoimi procedurami) spółkom, które potrafią wiarygodnie udokumentować wykonalność i jakość prowadzonych przez siebie projektów. W fazie zagospodarowania złoża podstawą decyzji o podjęciu ryzyka finansowania projektu górniczego jest Bankowe studium wykonalności BSW (ang. Bankable feasibility study) przygotowane pod kątem wymagań banku lub innych instytucji finansowych. Jest to kompleksowe studium techniczno-ekonomiczne możliwości ekonomicznie opłacalnego wydobycia części zasobów geologicznych złoża kopaliny z uwzględnieniem wszelkich czynników geologiczno-górniczych, technicznych, ekonomicznych, marketingowych, prawnych, środowiskowych oraz istotnych względów społecznych i administracyjnych (Whittle i in. 2007; Nelson 2011). Coraz większą aktywność na rynku surowcowym wykazują fundusze inwestycyjne oraz typu venture capital. To zaangażowanie w projekty surowcowe należy wiązać zarówno z atrakcyjnością rynku projektów surowcowych, jak i dywersyfikacją portfela produktowego, pozwalającego na ograniczanie ryzyka cykliczności gospodarki czy cen oraz bardziej przewidywalne przepływy finansowe. Wiązać to zjawisko można także ze światowym kryzysem finansowym spowodowanym m.in. niekontrolowanym rozwojem tzw. finansowych instrumentów pochodnych (derywatów-zwłaszcza towarowych), które przez kilka lat konsumowało nadwyżki na rynku inwestycyjnym i stwarzało pozorne obszary wysokich zysków dla drobnych inwestorów.

Celem artykułu jest ukazanie zakresu wymagań analitycznych ze strony międzynarodowych instytucji finansujących na różnych etapach realizacji zawartych w dokumencie BSW, dotyczącym projektu górniczego. Przedstawiono znaczenie studium wykonalności, jako użytecznego narzędzia zarządzania ryzykiem projektu (w szczególności w zakresie trafności rozwiązań projektowych) oraz oceny jego rentowności w procesie decyzyjnym finansowania, a następnie realizacji projektu górniczego. Zanim dochodzi do wykonania projektu w sensie rzeczowym, etap wdrożenia (budowa zakładu górniczego) poprzedza faza koncepcyjna przygotowania projektu, która kończy się podjęciem decyzji inwestycyjnej lub decyzji o zaniechaniu realizacji analizowanego przedsięwzięcia.

W fazie opracowywania i analizy koncepcji, a następnie wariantów projektu, na etapach studium wykonalności ma miejsce identyfikacja istotnych, związanych z nim czynników ryzyka warunkujących efektywność i opłacalność przedsięwzięcia (Park i Nelson 2013). 


\section{Międzynarodowe standardy raportowania dla potrzeb finansowania projektów górniczych}

Wymagania stawiane przez międzynarodowe instytucje finansowe (banki, giełdy, fundusze) w zakresie raportowania wyników prac geologicznych oraz wykonalności i oceny ekonomicznej projektów górniczych dla potrzeb ich finansowania wymuszają konieczność stosowania międzynarodowej standaryzacji klasyfikacji zasobów kopalin oraz unifikacji raportowania wyników prac geologicznych.

Celem tej standaryzacji jest umożliwienie porównania wartości ekonomicznej zasobów złoża kopaliny według jednolitych zasad i traktowania zasobów kopaliny jako składnika aktywów przedsiębiorstw górniczych.

W Polsce funkcjonuje pojęcie aktywów geologiczno-górniczych wprowadzone do obiegu zwłaszcza przez Polski Kodeks Wyceny Złóż Kopalin PolVal (PolVal) opracowany i przyjęty przez Polskie Stowarzyszenie Wyceny Złóż Kopalin. Pojęcie to jest używane jednak zbyt rzadko i nie ma charakteru obowiązującego. „Aktywem” są zasoby kopalin i powinno się je uważać za depozyty majątkowe w rozumieniu prawa bilansowego. Brak regulacji prawno-bilansowych w tym zakresie powoduje znaczne różnice w podejściu do wyceny polskich spółek górniczych (Saługa 2009; Uberman i Galos 2013).

W międzynarodowych instytucjach finansowych dla potrzeb finansowania projektów górniczych najczęściej jest stosowany australijski system raportowania wyników rozpoznania złoża oraz oceny jego zasobów znany pod nazwą JORC Code (JORC 2012).

\subsection{System klasyfikacji zasobów JORC}

System JORC stosowany jest jako system sprawozdawczości w międzynarodowych przedsięwzięciach obejmujących poszukiwanie i rozpoznawanie złóż kopalin (Beniscelli i in. 2000; Scott i Whateley 2006). Jego pełna nazwa to - The Australasian Code for Reporting of Exploration Results, Mineral Resources and Ore Reserves. Został on opracowany w roku 1971 przez Joint Ore Reserves Committee (JORC) i jest głównym systemem sprawozdawczości stosowanym w Australii, Kanadzie, Republice Południowej Afryki, Stanach Zjednoczonych, Wielkiej Brytanii i Irlandii. Jest również akceptowany przez wiele krajów w Europie (w tym w Polsce) na skutek przyjęcia umowy o inkorporowaniu definicji CMMI (Council of Mining and Metallurgical Institutions) do systemu Międzynarodowej ramowej klasyfikacji zasobów złóż kopalin (International Framework Classification for Reserves and Resources - Solid Fuels and Mineral Commodities) stworzonej przez Europejską Komisję Gospodarczą ONZ (UNECE) (Nieć 2009).

Głównym celem JORC Code jest określenie wymagań odnośnie: metodyki kategoryzacji zasobów złóż (szacowania), formy przekazywania informacji o udokumentowanych zasobach kopaliny, publikowania danych o wielkości i jakości zasobów dla potrzeb instytucji finansujących dany projekt oraz sprawozdawczości publicznej, między innymi sporządza- 
nia obowiązkowych raportów spółek notowanych na giełdzie (ang. Public Reports, PR). Istotnym elementem tego systemu raportowania są również wymagania odnośnie kwalifikacji ekspertów sporządzających PR, określanych jako osoba kompetentna (ang. Competent Person, CP), o uznanym doświadczeniu i pozycji zawodowej. Osoba kompetentna musi posiadać przynajmniej 5 lat doświadczenia w dokumentowaniu danego rodzaju kopaliny i typu złóż (JORC 2012). Jako competent person może występować posiadacz tytułu zawodowego European geologist przyznawanego przez European Federation of Geologists (http://eurogeologists.eu). W obecnym stanie prawnym, osoba posiadająca kwalifikacje geologiczne (tzw. uprawnienia) przyznane w Polsce przez ministra środowiska nie spełnia warunków uznania jej za competent person.

W odniesieniu do metodyki kategoryzacji zasobów złóż kopalin stałych JORC Code zawiera bardzo ważne dla szacowania zasobów wymagania dotyczące minimalnych uzysków rdzenia oraz maksymalnych (dopuszczalnych) rozstawów punktów rozpoznania geologicznego (punktów obserwacji).

JORC Code wyróżnia dwa rodzaje zasobów złóż kopalin stałych: resources (zasoby bilansowe) i reserves (zasoby eksploatacyjne lub wydobywalne) (rys. 1).

$\mathrm{W}$ obrębie resources wyróżnia się trzy kategorie stopnia ich zbadania w zależności od poziomu zaufania do oszacowań parametrów złoża (miąższości, głębokości zalegania, jakości kopaliny i jej zasobów):

1) inferred (zasoby przypuszczalne),

2) indicated (zasoby wykazane),

3) measured (zasoby pomierzone).

Ostateczna decyzja, co do ustalenia kategorii zasobów należy do osoby kompetentnej.

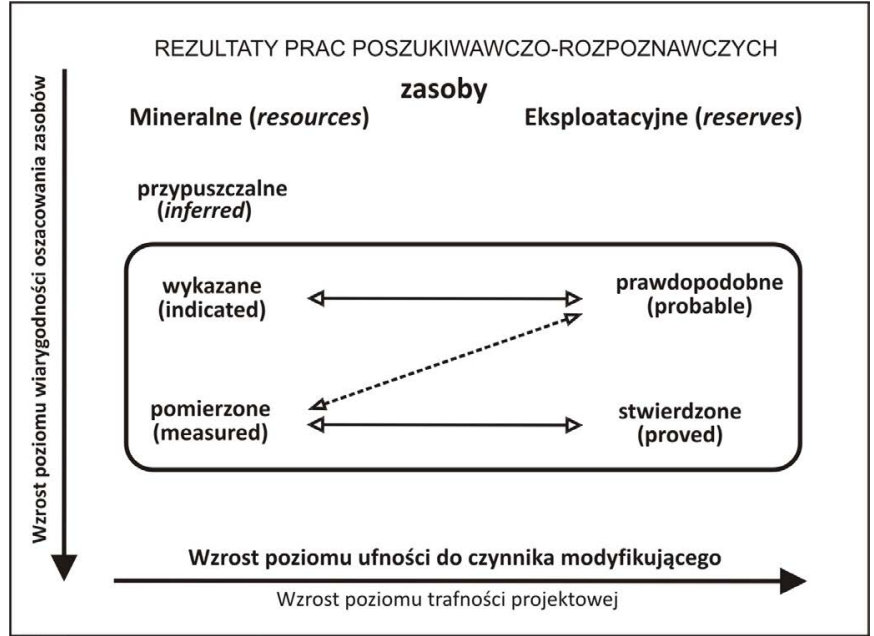

Rys. 1. Schemat przedstawiający relacje między dokładnością rozpoznania a wyróżnionymi klasami zasobów w klasyfikacji JORC 2012

Fig. 1. Diagram showing the relationship between exploration results, mineral resources and ore reserves, JORC Code 2012 
Kategorie zasobów zgodne z JORC Code można następująco skorelować z polskimi kategoriami stopnia zbadania złoża:

1) inferred - kategoria $\mathrm{D}+\mathrm{C}_{2}$,

2) indicated - kategoria $\mathrm{C}_{2}, \mathrm{C}_{1}$,

3) measured - kategoria A + B.

Polskie określenia kategorii zasobów należy traktować jako orientacyjne z uwagi na trudności z trafnym dopasowaniem polskich odpowiedników. To, jak również znaczne różnice w odniesieniu do metodyki kategoryzacji zasobów złóż kopalin powodują, że informacje o ilości i jakości zasobów kopaliny zawarte w polskich dokumentacjach geologicznych złóż są nieporównywalne z tymi podawanymi zgodnie z JORC Code (Wierchowiec $\mathrm{i}$ in. 2013).

Głównym przedmiotem kontrowersji jest sposób rozumienia terminów resources i reserves nie mających prostych odpowiedników w klasyfikacji polskiej, a mających fundamentalne znaczenie dla oceny ekonomicznej projektów górniczych dla potrzeb ich finansowania (Nieć 2009).

Resources stanowią zasoby mineralne oceniane tylko na podstawie danych geologicznych - wykorzystanie których jest potencjalnie możliwe, ale warunki i możliwości zagospodarowania tych zasobów nie są dostatecznie określone. Ocena opłacalności wydobycia kopaliny opiera się na studium ewaluacyjnym (analizy możliwości) (ang. Scoping study) (Nelson 2011)

Studium ewaluacyjne pozwala dokonać wstępnej oceny wykonalności przedsięwzięcia i poziomu jego efektywności finansowej. W wypadku negatywnej oceny wykonalności przedsięwzięcia, opracowanie studium różnych możliwości i koncepcji zagospodarowania zasobów geologicznych pozwala na etapie wstępnym uniknąc wysokich kosztów związanych ze szczegółową analizą i oceną możliwości zagospodarowania złoża. W efekcie studium ewaluacyjne może się okazać początkiem gromadzenia środków finansowych, bowiem potencjalni inwestorzy są zainteresowani uzyskaniem informacji na temat nowych, zidentyfikowanych możliwości inwestycyjnych.

Reserves rozumiane są jako zasoby wydobywalne, eksploatacyjne - a zatem możliwa do ekonomicznie opłacalnego wydobycia część zasobów pomierzonych i/lub wykazanych z uwzględnieniem czynników zubażających (zanieczyszczenia kopaliny oraz ewentualne przybierki, które mogą być konieczne w trakcie wydobycia) oraz modyfikujących, takich jak: uwarunkowania geologiczno-górnicze, technologiczne, infrastrukturalne, ekonomiczne, marketingowe, prawne, środowiskowe, społeczno-polityczne i administracyjne (m.in. przestrzennego zagospodarowania terenu). W przypadku zasobów kopaliny zaliczonych do reserves ocena opłacalności wydobycia opiera się na studium techniczno-ekonomicznym projektu górniczego i realizowana jest na dwóch etapach zgodnie z rosnącym poziomem ufności do posiadanej wiedzy geologicznej oraz informacji o czynnikach modyfikujących, mogących w znacznym stopniu ograniczyć możliwości zagospodarowania złoża: wstępnego studium wykonalności projektu (ang. Preliminary feasibility study) oraz ostatecznego bankowego studium wykonalności projektu (ang. Feasibility study = Bankable feasibility study) (rys. 2). 


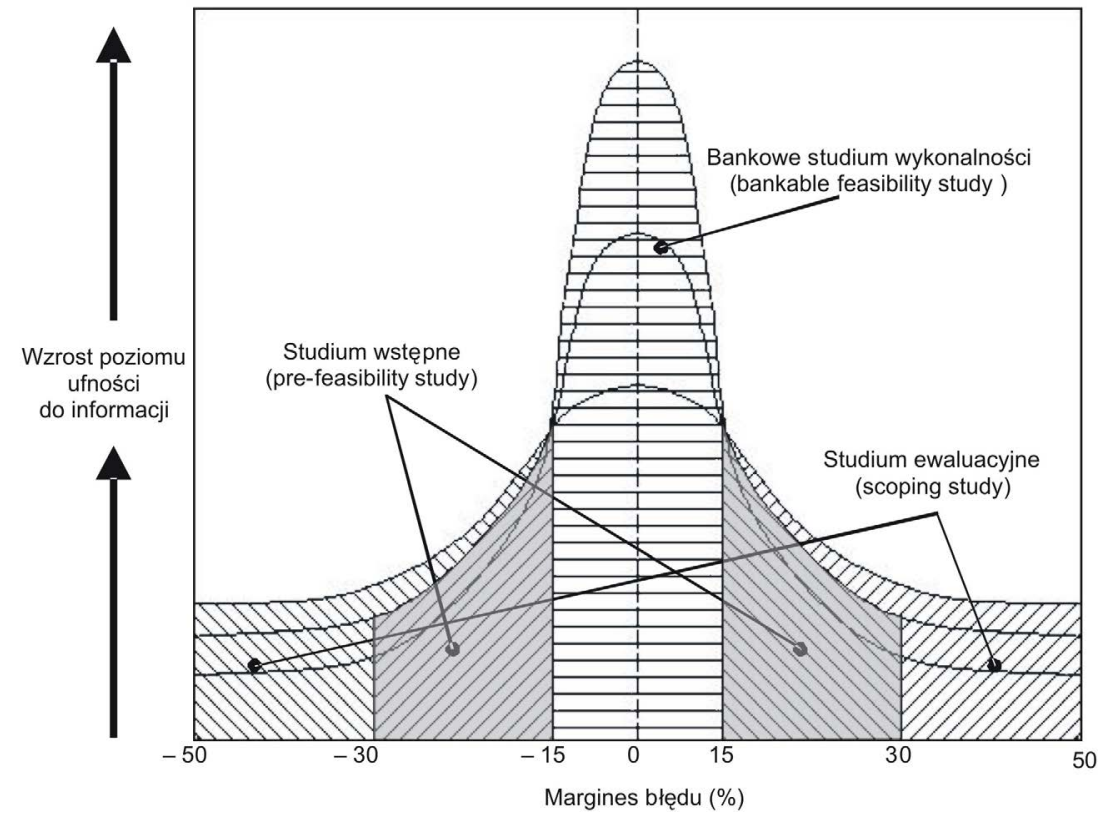

Rys. 2. Wykres obrazujący skale wiarygodności (poziomu ufności) projektu górniczego na różnych etapach jego realizacji (Behrens i Hawranek 1993, zmienione)

Fig. 2. Diagram showing the engineering accuracy (confidence level) mining project at various stages of its execution (Behrens and Hawranek 1993, modified)

Wyróżnia się dwie podkategorie zasobów typu reserves zgodnie z rosnącym poziomem wiarygodności oszacowania zasobów (ufności do informacji geologicznej) i trafności projektowej (możliwości zagospodarowania złoża) (rys. 1):

1) prawdopodobne (probable) - ekonomicznie opłacalna eksploatacja części zasobów wykazanych oraz, w pewnych okolicznościach, pomierzonych;

2) stwierdzone (proved) - ekonomicznie opłacalna eksploatacja części zasobów pomierzo-

nych.

Opierając się na czynnikach modyfikujących może być konieczna odpowiednia zmiana wyliczeń dotyczących zasobów prawdopodobnych (JORC 2012). Celem powyższych szacowań jest wykazanie, że w momencie ich tworzenia eksploatacja byłaby zasadna. Ponieważ poziom ufności czynników modyfikujących uwzględnionych przy szacowaniu zasobów prawdopodobnych jest niższy niż w przypadku zasobów stwierdzonych, w sytuacji wzrostu ufności chociażby do uwarunkowań ekonomicznych, marketingowych czy społecznych zasoby prawdopodobne mogą być przeszacowane do stwierdzonych (rys. 1).

Szacowanie zasobów typu reserves oraz podział na powyższe podkategorie jest realizowane w ramach studium wykonalności projektu i leży w gestii odpowiednio wykwalifikowanego eksperta mogącego spełniać rolę osoby $C P$.

Wielkość zasobów eksploatacyjnych ma podstawowe znaczenie dla międzynarodowych instytucji finansujących projekty górnicze oraz udziałowców koncernów mineralnych, 
w związku z powyższym dla spółek notowanych na giełdzie zasoby stwierdzone i prawdopodobne muszą być obowiązkowo wydzielone, najdalej na etapie bankowego studium wykonalności projektu. Zatem studium wykonalności danego projektu jest tym działaniem, które „przekształca” zasoby mineralne (resources) w eksploatacyjne (reserves). Ma to kardynalne znaczenie dla wyceny wartości projektu i możliwości jego dalszego rozwoju (finansowania), gdyż międzynarodowe instytucje finansujące jako składnik aktywów przedsiębiorstw górniczych traktują wyłącznie zasoby eksploatacyjne (Beniscelli i in. 2000; Bullock 2011a).

W warunkach gospodarki rynkowej, gdy o zaliczeniu zasobów do kategorii eksploatacyjnych decydują zmienne czynniki ekonomiczne, właściwe planowanie zagospodarowania zasobów złóż kopalin praktycznie może być realizowane tylko poprzez profesjonalnie wykonane bankowe studium wykonalności projektu, w którym określany jest poziom opłacalności i ryzyko niepowodzenia projektu górniczego.

\subsection{Podstawy metodyki kategoryzacji zasobów złóż kopalin zgodnie z JORC Code}

Fundamentalną zasadą metodyki kategoryzacji zasobów w systemie JORC Code jest zabezpieczenie rzetelności danych wyjściowych realizowane poprzez wymagania dotyczące minimalnych uzysków rdzenia wiertniczego. Przykładowo, wytyczne JORC określają, że uzysk rdzenia z otworu badawczego musi wynosić co najmniej 95\% długości rdzenia (JORC 2012). Jeżeli uzysk jest mniejszy, dane z punktu obserwacyjnego powinny być odrzucone z uwagi na niereprezentatywność danych geologicznych. Osoba kompetentna (CP) może złagodzić to kryterium do wartości około $90 \%$ w przypadku, gdy dysponuje dobrymi danymi pomocniczymi (np. dane geofizyki otworowej), które pozwalają na oszacowanie miąższości złoża z dosyć dużą dokładnością. Należy jednak odrzucić wszystkie te dane geologiczne, które otrzymano na bazie rdzeni o uzysku poniżej $90 \%$. Takie rdzenie z niższym uzyskiem nie mogą być wykorzystane do szacowania oraz klasyfikowania zasobów kopaliny. Stanowi to bardzo poważny problem, w sytuacji kiedy mamy do czynienia z szacowaniem zasobów i ich kategoryzacją opartą na bazie historycznych danych otworowych. W Polsce bowiem często szacunki zasobów złóż oraz ich klasyfikację wykonywano przy uzyskach rdzeni wynoszących $50-80 \%$ (Wierchowiec i in. 2013).

W takich przypadkach jedynym rzetelnym sposobem oszacowania zgodnego ze standardami JORC jest ponowna analiza danych wyjściowych przeprowadzona przez osobę kompetentną $(\mathrm{CP})$ w celu opracowania nowego, niezależnego oszacowania zasobów.

W odniesieniu do metodyki kategoryzacji zasobów, JORC Code zawiera również bardzo ważne, z punktu szacowania zasobów, wymagania dotyczące maksymalnych (dopuszczalnych) rozstawów punktów rozpoznania geologicznego (obserwacji). W zależności od złożoności budowy geologicznej złoża, kompetentna osoba (CP) może zróżnicować rozmieszczenie punktów obserwacyjnych (zwykle wierceń) dla poszczególnych kategorii rozpoznania, lecz nie jest to kategoryzacja zmienności złoża, jak w systemie polskim, posługującym się trzema zdefiniowanymi grupami skomplikowania budowy geologicznej złoża (Nieć 2002). 
W sytuacjach, kiedy uzyski rdzenia są niewystarczające dla zaliczenia zasobów do wymaganej kategorii istnieje konieczność wykonania dodatkowych wierceń rozpoznawczych. Decyzja, co do ich ilości i lokalizacji leży w gestii osoby kompetentnej (CP).

Zgodnie z wymogami JORC Code realistyczna i aktualna ocena wykazująca, że wydobycie kopaliny jest możliwe technicznie i opłacalne ekonomicznie przy przyjęciu uzasadnionych założeń finansowych jest realizowana na etapie studium wykonalności danego projektu. W praktyce oznacza to, że plan i harmonogram wydobycia kopaliny są tworzone w połączeniu z modelem finansowym w horyzoncie czasowym od 10 do maksimum 20 lat. Nie ma bowiem możliwości wystarczająco dokładnego modelowania zdyskontowanych kosztów wydobycia w horyzoncie czasowym powyżej 20 lat (Scott i Whateley 2006; Park i Nelson 2013).

\section{Studium wykonalności jako narzędzie oceny poziomu ryzyka inwestycyjnego}

Inwestycje przemysłu wydobywczego (projekty górnicze) są, co do zasady, przedsięwzięciami złożonymi pod względem technologicznym, ekonomiczno-finansowym, prawnym i instytucjonalnym. $Z$ tego powodu projektom górniczym towarzyszą różne czynniki ryzyka, które winny być zidentyfikowane w fazie opracowywania koncepcji i różnych wariantów projektu oraz monitorowane w fazie jego rzeczowej realizacji (Berry 2009; Nelson 2011).

Podstawową zasadą przygotowania górniczych projektów inwestycyjnych do realizacji jest uwzględnienie kolejności i wymagań cyklu inwestycyjnego, co w praktyce przekłada się na następujące działania (rys. 3):

a) określenie potencjału zasobowego poprzez oszacowanie zasobów zgodnie z międzynarodowymi standardami raportowania (CSA 2011; JORC Code 2012);

b) opracowanie studium możliwości i różnych koncepcji zagospodarowania zasobów geologicznych (studium ewaluacyjne);

c) przeanalizowanie różnych wariantów projektu z uwzględnieniem uwarunkowań geologiczno-górniczych, technologicznych, infrastrukturalnych, ekonomicznych, marketingowych, prawnych, środowiskowych (określenie oddziaływania projektu na środowisko oraz zdrowie ludzi), społecznych i administracyjnych oraz wybór wariantu optymalnego ze względu na cel, który ma być osiągnięty (studium wstępne);

d) kalkulacja nakładów inwestycyjnych i ustalenie efektywności ekonomicznej projektu oraz montaż finansowy (opracowanie wskazujące źródła finansowania przedsięwzięcia) z uwzględnieniem kosztów kwalifikowanych, kosztów niekwalifikowanych oraz podatków (studium ostateczne, zawarcie umów);

e) opracowanie harmonogramu wdrożenia projektu (budowa zakładu górniczego i jego rozruch).

Złożoność tego typu projektów oraz wielostronne czynniki ryzyka związane z ich oceną i wdrożeniem prowadzą do konieczności poszukiwania w procesie decyzyjnym instrumentu 


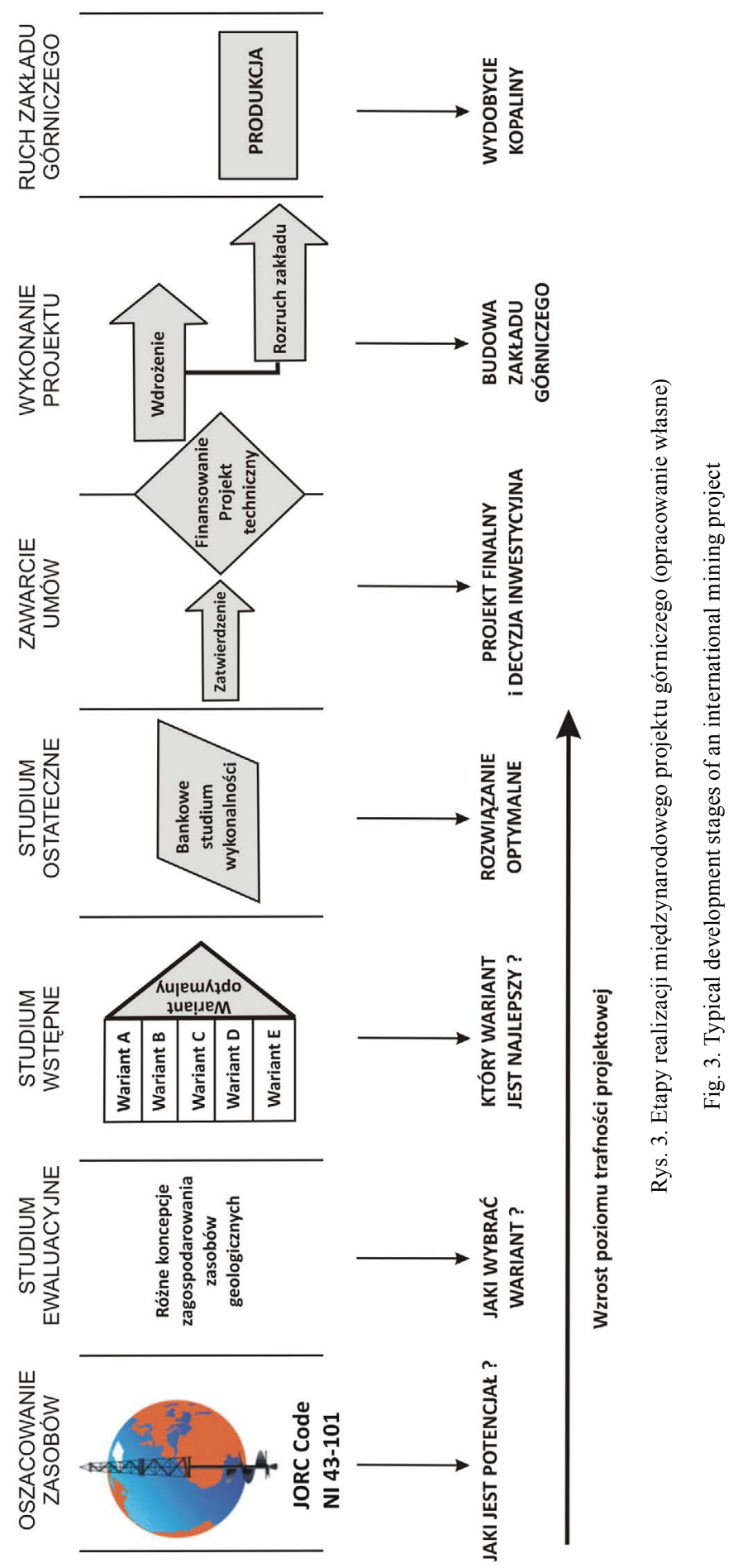


oceny rentowności projektu. W fazie przedinwestycyjnej projektu górniczego taką funkcję spełnia Bankowe Studium Wykonalności (BSW). Dokument ten pozwala w sposób wiarygodny ocenić poziom ryzyka finansowego oraz zarządzać tym ryzykiem na etapie studium techniczno-ekonomicznego i uniknąć bezpośredniego przechodzenia od fazy koncepcyjnej (studium ewaluacyjne), która często nie wymaga ponoszenia znaczących kosztów przez inwestora - do fazy wykonawczej (budowa zakładu górniczego), wymagającej zaangażowania znacznych środków finansowych i nakładu pracy.

Celem BSW jest dostarczenie wszelkich danych istotnych do podjęcia decyzji inwestycyjnej, zarówno samemu inwestorowi, jak i instytucjom finansującym, które na jego podstawie przeprowadzają ocenę trafności projektowej (pewności powodzenia technicznego proponowanych rozwiązań w zakresie eksploatacji złoża) oraz rentowności inwestycji. W związku z tym studium BSW uwzględnia wszystkie możliwe do przewidzenia czynniki ryzyka inwestycyjnego oraz wszelkie aspekty społeczno-polityczne warunkujące wykonalność projektu oraz jego efektywność finansową.

Ten etap analizy ma za zadanie zbadać, czy i jakie czynniki utrudniają bądź uniemożliwiają przeprowadzenie projektu. W każdym z wymienionych aspektów projekt musi być wykonalny, aby zidentyfikować i zniwelować ryzyko związane z jego realizacją.

\subsection{Ryzyko w projektach górniczych}

Przez ryzyko (miarę niepewności) w projektach górniczych rozumie się możliwość powstania odchyleń od zamierzonych efektów działania (Chapman i Ward 2004). Odchylenia te mogą być przewidziane za pomocą rachunku prawdopodobieństwa. Jest wiele dostępnych metod uwzględnienia ryzyka w analizach opłacalności - analiza wrażliwości, analiza scenariuszy, analiza drzew decyzyjnych, analiza symulacyjna (np. symulacja Monte Carlo, warunkowa), równoważnik pewności, NPV ze stopą dyskontową uwzględniająca ryzyko RADR, metoda opcji realnych i teorii gier strategicznych (Vose 2008; Saługa 2009; Park i Nelson 2013).

Zarządzanie ryzykiem może być rozumiane jako proces formułowania planu działania zmierzającego do optymalizacji ryzyka w funkcjonowaniu podmiotu i do podejmowania w tym celu racjonalnych decyzji nakierowanych na minimalizację lub eliminację negatywnych skutków ryzyka, ujawniającego się w różnych obszarach funkcjonowania danej spółki górniczej.

Proces zarządzania ryzykiem obejmuje następujące główne fazy (Kaczmarek 2006):

- identyfikacja i analiza ryzyka,

- ocena i sformułowanie wariantów przeciwdziałania,

- ograniczanie i eliminowanie przyczyn ryzyka,

- kontrola, monitoring i ocena skuteczności podjętych działań.

Odnosząc kwestie zarządzania ryzykiem do zarządzania projektami górniczymi, ocena zasadności projektu pod kątem relacji nakładów do efektów oraz identyfikacja czynników ryzyka dokonywane są w fazie trzyetapowego studium wykonalności projektu (rys. 3). 
Ryzyko dotyczące realizacji (wykonania) górniczego projektu inwestycyjnego ma charakter wielowymiarowy i wieloaspektowy. Czynniki ryzyka, które mogą wpływać na wykonalność projektu są różnorodne i można je sklasyfikować według różnych kryteriów (Beniscelli i in. 2000; Vose 2008; Berry 2009).

Identyfikując kategorie ryzyka w projektach górniczych można wskazać następujące, istotne obszary ryzyka, warunkujące powodzenie jego przeprowadzenia (Mucha i in. 2007; Bullock 2011a; Park i Nelson 2013):

a) ryzyko niepewności odnośnie wielkości i jakości zasobów, warunków geologiczno-górniczych oraz zagrożeń naturalnych;

b) ryzyko dotyczące planowanych rozwiązań technicznych i technologicznych - takiemu ryzyku ma zapobiec analiza zakresu rzeczowego i możliwych wariantów realizacji projektu;

c) ryzyko prawne i instytucjonalne - w tym zakresie mieszczą się częste zmiany przepisów prawnych i podatkowych czy np. nieuregulowane kwestie własności gruntów;

d) ryzyko zachowania ram czasowych projektu - takiemu ryzyku ma zapobiec przygotowanie w fazie projektowania harmonogramu uwzględniającego możliwe, czasowe przesunięcia terminów realizacji poszczególnych etapów projektu;

e) ryzyko finansowe, związane z opracowanym budżetem zadań i działań oraz źródłami finansowania projektu oraz ryzyko błędnej kalkulacji efektów ekonomiczno-finansowych - ograniczaniu tej kategorii ryzyka służy opracowanie rachunku kosztów i korzyści oraz analiza wrażliwości głównych wskaźników charakteryzujących projekt, w sytuacji zmian istotnych składników, na przykład kosztów inwestycyjnych.

\section{Bankowe studium wykonalności - cele sporządzenia i zakres analiz}

Podstawowym celem przygotowania Bankowego studium wykonalności dla górniczego projektu inwestycyjnego jest szczegółowa analiza badanego przedsięwzięcia pod kątem jego wykonalności w aspekcie technicznym (uwarunkowania geologiczno-górnicze), technologicznym, prawnym, instytucjonalnym, ekonomiczno-finansowym, ze względu na wymogi ochrony środowiska (konfliktu eksploatacji złoża ze środowiskiem) oraz analiza w odniesieniu do potencjalnego wpływu społecznego inwestycji (zarówno pozytywnego jak i negatywnego). Bankowe studium wykonalności składa się z wyodrębnionych części, zawierających szczegółowe analizy projektu w każdym z wymienionych aspektów.

Pozwala to między innymi na (Behrens i Hawranek 1993; Bullock 2011b):

a) określenie zakresu rzeczowego przedsięwzięcia (projektu) oraz jego głównych parametrów technicznych;

b) oszacowanie nakładów inwestycyjnych oraz określenie ich harmonogramu realizacji, co pozwala na zaplanowanie wydatków, a także określenie i zatwierdzenie (zawarcie umów) źródeł sfinansowania projektu; 
c) określenie oddziaływania projektu na środowisko i zdrowie ludzi oraz dobranie adekwatnych do jego pomiaru wskaźników umożliwiających wycenę pieniężną poszczególnych dóbr przyrodniczych;

d) ocenę, czy analizowana inwestycja jest uzasadniona i akceptowalna ze społecznego punktu widzenia;

e) potwierdzenie zasadności wybranego do realizacji wariantu projektu;

f) stwierdzenie istnienia lub braku istotnych zagrożeń związanych z realizacją i eksploatacją analizowanego projektu.

Zatem celem przeprowadzanych analiz jest wykazanie zasadności przeprowadzenia planowanego przedsięwzięcia, określenie jego ram czasowych i organizacyjnych oraz ocena rentowności projektu jako całości.

\subsection{Aspekty środowiskowe i spoleczne w świetle wymogów międzynarodowych instytucji finansowych}

W odniesieniu do aspektów środowiskowych i społeczno-socjalnych najlepsze praktyki międzynarodowe i konkretne wymogi instytucji finansujących (banków) w zakresie opracowania bankowego studium wykonalności projektu wymuszają poza procedurami Ocen oddziaływania na środowisko (OOŚ) zgodnie z właściwymi przepisami prawa polskiego (Ustawa 2008) dodatkowe uzgodnienia z kredytodawcami.

Operator projektu zobligowany jest do sporządzenia Planu Dziatań Środowiskowych $i$ Społecznych (ang. Environmental and social action plan, ESAP) podsumowujący kluczowe pozycje działań z Decyzji środowiskowej wydanej przez właściwe władze polskie (zgodnie z mającymi zastosowanie przepisami polskimi/UE), który dodatkowo zawiera szereg działań dla zabezpieczenia aspektów środowiskowych i społecznych realizacji projektu zgodnie z wymaganiami kredytodawców. ESAP oparty jest na zastosowaniu do projektów inwestycyjnych tzw. Zasad równikowych (ang. Equator principles, EP) i wynikających z nich standardów (Equator Principles 2013) oraz wymagań i standardów Międzynarodowej Korporacji Finansowej (ang. International Finance Corporation, IFC), agencji działającej w ramach Grupy Banku Światowego (IFC 2012). Zasady te, przyjęte przez czołowe światowe instytucje finansowe, określają standardy odpowiedzialności środowiskowej i społeczno-socjalnej w zakresie zarządzania ryzykiem finansowym projektów rozwojowych (w tym górniczych), jeżeli finansowany jest projekt o wartości przekraczającej $10 \mathrm{mln}$ \$. Obecnie zgodnie z przyjętymi wymogami i standardami działa 80 instytucji finansowych w 34 krajach świata (w tym w Polsce), a ich udział w finansowaniu projektów na rynkach wschodzących, do których jest również zaliczany nasz kraj, wynosi ponad $70 \%$.

W ramach EP i IFC został opracowany międzynarodowy standard i jeden wspólny odnośnik do określenia oddziaływania projektów na środowisko i społeczność lokalną niezależnie od lokalizacji projektu na świecie. Aplikacja tych standardów do opracowania bankowe- 
go studium wykonalności projektu pozwala na wczesne oszacowanie potencjalnych ryzyk przy ocenie rentowności przedsięwzięcia.

\subsection{Wymogi środowiskowe i społeczne wynikające ze standardów EP-IFC}

Na etapie bankowego studium wykonalności standardy odpowiedzialności środowiskowej i społecznej wymuszają przygotowanie Planu działań środowiskowych i spolecznych (ESAP) zawierającego działania środowiskowe, jak również społeczne, mające na celu zarządzanie, łagodzenie i monitorowanie zagrożeń zidentyfikowanych w trakcie przygotowywania raportu środowiskowego (procedura OOŚ) i przedstawienie ich w formie syntetycznego, tabelarycznego zestawienia zobowiązań dotyczących środowiska, kwestii społecznych, bezpieczeństwa zdrowia, bezpieczeństwa publicznego, zatrudnienia, jak i innych kwestii specyficznych dla danego projektu. Standardy EP-IFC zalecają, aby monitoring wdrażania planu działań prowadzony był przez niezależnego konsultanta w imieniu kredytodawców.

\subsubsection{Ocena oddziaływania na środowisko i społeczność lokalną}

Zobowiązania dotyczące ochrony środowiska i działań społecznych są realizowane poprzez wykonanie Oceny oddzialywania na środowisko naturalne oraz wplywu inwestycji na lokalne społeczności (ang. Environmental and Social Impact Assessment, ESIA) (Vanclay i Bronstein 1995; Vanclay 2003; Cloquell-Ballester i in. 2006).

Częścią składową tej oceny jest wykonanie analizy obszaru zajętego pod inwestycję pod kątem tzw. usług ekosystemowych, czyli usług świadczonych przez ekosystemy znajdujące się w obszarze oddziaływania projektowanej inwestycji (Costanza i in. 1997; Solon 2008). Celem tej analizy jest racjonalizacja umiejscowienia różnych elementów inwestycji w taki sposób, aby koszt środowiskowy był wyeliminowany bądź jak najmniejszy. Opracowanie powinno zawierać m.in. mapowanie ekosystemów, identyfikację i charakterystykę funkcji ekosystemów w obszarze oddziaływania projektu, charakterystykę usług ekosystemowych świadczonych przez ekosystemy, w tym ich opis, kategoryzację, ilościową ocenę, wycenę usług oraz analizę trendów w przepływie usług w wybranym przedziale czasu (De Groot $i$ in. 2002; Kremen 2005; Balvanera i in. 2006).

Zgodnie z właściwymi przepisami prawa polskiego Raport (ocena) o oddziaływaniu przedsięwzięcia na środowisko jest opracowaniem techniczno-przyrodniczym i nie analizuje aspektów społecznych planowanej inwestycji (Ustawa 2001; Ustawa 2008).

Ocena oddziaływania na środowisko (OOŚ) pozwala jedynie przeanalizować możliwości realizacji inwestycji w taki sposób, by była ona bezpieczna dla środowiska i nie stwarzała zagrożenia dla bioróżnorodności. OOŚ oraz formalne decyzje i pozwolenia wymagane przed etapem realizacji Projektu koncentrują się na aspektach środowiskowo-ekologicznych. $\mathrm{W}$ obecnym stanie prawnym inwestor nie odpowiada za udział społeczeństwa $\mathrm{w}$ procesie inwestycyjnym. Obowiązek ten spoczywa na organach administracji publicznej (Ustawa 
2008). Inwestor udostępnia Raport o oddzialywaniu przedsięwzięcia na środowisko za pośrednictwem organu administracji publicznej do wglądu opinii publicznej.

Niemniej standardy EP-IFC stanowią, że wymagane jest określenie potencjalnego wpływu społecznego Projektu oraz wdrożenie odpowiednich działań ograniczających. W praktyce działania dostosowawcze do powyższych standardów polegają na przygotowaniu i przedstawieniu informacji o elementach nieobjętych procedurą OOŚ zgodnie z właściwymi przepisami prawa polskiego $\mathrm{w}$ formie uzupełnienia do raportu/procedury OOŚ.

W ramach działan dostosowawczych (uzupełniających) inwestor realizujący projekt zobowiązany jest do przeprowadzenia i przedstawienia w formie dokumentu Analizy spolecznej (ang. Social review, SR), która obejmuje ocenę informacji zebranych w ramach procedury ESIA w odniesieniu do potencjalnego wpływu społecznego projektu (zarówno pozytywnego jak i negatywnego) oraz opracowania Planu działań dla zachowania bioróżnorodności (ang. Biodiversity action plan, BAP) w kontekście standardów EP-IFC odnoszących się do różnorodności biologicznej oraz usług świadczonych przez ekosystemy, znajdujące się w obszarze oddziaływania projektowanej inwestycji.

W praktyce sprowadza się to do dokonania oceny, w jakim stopniu działania związane z realizacją Projektu wpłyną na różnorodność gatunkową i poszczególne składniki ekosystemu oraz jak można przeciwdziałać ewentualnym negatywnym konsekwencjom tego działania.

Skala negatywnych reakcji ekosystemów na nową formę użytkowania, jaką będzie realizacja projektowanego przedsięwzięcia, jest wyceniana poprzez oszacowanie kosztów związanych z zamianą usług ekosystemowych (Balvanera i in. 2006).

Analiza społeczna i Plan działań dla zachowania bioróżnorodności są dokumentami obligatoryjnymi dla bankowego finansowania Projektu zgodnie ze standardami EP-IFC (Equator Principles 2013).

\subsubsection{Plan współpracy z zainteresowanymi stronami}

Standardy EP-IFC dla ocen oddziaływania na środowisko naturalne (ESIA) dla wszystkich projektów górniczych, które wymagają formalnej oceny oddziaływania na środowisko stanowią, że operator projektu górniczego powinien przeprowadzać transparentne i dostosowane kulturowo konsultacje społeczne dla zainteresowanej społeczności lokalnej oraz ujawniać w odpowiednim czasie i formie wymagane informacje. Zazwyczaj odbywa się to poprzez zamieszczenie na stronie internetowej dokumentacji procesu oceny skutków środowiskowych i społecznych.

W ramach wymogu konsultacji inwestor (operator projektu) ma obowiązek przygotowania i opublikowania Planu wspótpracy z zainteresowanymi stronami (ang. Stakeholder Engagement Plan, SEP). Powyższy dokument zawiera szczegółowe informacje na temat działań podejmowanych $\mathrm{w}$ celu publicznego informowania o inwestycji oraz o mechanizmie rozpatrywania skarg i składania zapytań przez zainteresowane strony. Dodatkowo inwestor powinien udowodnić, że wyrażone przez lokalną społeczność opinie zostały rozwa- 
żone. Jest to realizowane poprzez wskazanie, które uwagi i wnioski społeczeństwa zostały uwzględnione w przygotowanym do realizacji wariancie projektu.

Udostępnienie informacji o projekcie umożliwia zainteresowanym stronom ocenę wpływu projektu inwestycyjnego na środowisko i społeczność lokalną, jak również poznanie korzyści płynących z realizacji samego projektu.

\section{Podsumowanie}

1. Studium wykonalności to prezentacja Projektu inwestycyjnego, na podstawie którego można ocenić kondycję ekonomiczno-finansową i opłacalność przedsięwzięcia (jego rentowność), które ma być finansowane - uwiarygodnienie projektodawcy (spółki geologicznej) przedsięwzięcia przy pozyskiwaniu środków zewnętrznych na realizację.

2. Banki, jako instytucje finansujące nowe przedsięwzięcia inwestycyjne, badają w głównej mierze płynność finansową firmy, zdolność kredytową i efektywność przedsięwzięcia. Najważniejsze dla banku stają się zabezpieczenia kredytu. Przygotowanie BSW projektu zgodnie z JORC Code zmniejsza ryzyko banków, a także samych przedsiębiorców, chociażby ze względu na przejrzystość danych, a tym samym zwiększa poziom ufności i ogranicza ryzyko niepowodzenia Projektu.

3. Integralną częścią projektów górniczych stają się zagadnienia środowiskowe i społeczno-socjalne oraz lad korporacyjny. Coraz więcej instytucji finansowych ocenia aspekty środowiskowe i społeczne zgodnie z wymogami międzynarodowych instytucji finansowych. Zarówno inwestorzy, jak i instytucje finansowe (prywatne lub instytucjonalne) biorą aspekty środowiskowe i społeczne pod uwagę podczas analiz Projektów, ponieważ czynniki środowiskowe mogą wpłynąć na wycenę aktywów i rentowność projektów. Na etapie BSW inwestor będzie musiał wdrożyć szereg działań w celu zapobiegania, ograniczania lub kontrolowania potencjalnych znaczących oddziaływań środowiskowych i społecznych, określonych w ocenie oddziaływania na środowisko, wymaganej zgodnie z prawem polskim, a także w celu zapewnienia zgodności z wymaganiami standardów EP-IFC. Wymagania te są przedstawione w formie planu działan środowiskowych i społecznych (ESAP) dla Projektu. ESAP następnie jest częścią porozumienia w sprawie finansowania pomiędzy inwestorem a instytucją finansującą (bankiem). Realizacja wymaganych działań jest raportowana do instytucji finansującej przynajmniej raz w roku i może być przedmiotem audytu lub innej oceny w całym okresie trwania Projektu.

Częścią składową oceny oddziaływania na środowisko jest wykonanie analizy obszaru zajętego pod inwestycję pod kątem usług świadczonych przez ekosystemy znajdujące się w obszarze oddziaływania projektowanej inwestycji. Celem tej analizy jest wycena ekonomiczna kosztów związanych z zamianą usług ekosystemowych w przypadku, gdy ulegną one negatywnym wpływom i racjonalizacja umiejscowienia różnych elementów inwestycji, w taki sposób, aby koszt środowiskowy był wyeliminowany bądź jak naj- 
mniejszy. Wczesne oszacowanie kosztów środowiskowych i społecznych ogranicza ryzyko niepowodzenia Projektu. Ze względu na zjawiska globalizacji aspektów środowiskowych oraz coraz szersze konflikty społeczne duże projekty górnicze muszą spełniać międzynarodowe wymagania $\mathrm{w}$ tym zakresie.

4. Poszukiwania geologiczne (jako najbardziej ryzykowny etap rozwoju projektu surowcowego) prowadzone w naszym kraju przez inwestora zagranicznego przynoszą Polsce wyłącznie korzyści. Za pieniądze inwestora pozyskuje się wiedzę geologiczną, zwiększa prawdopodobieństwo aktywizacji regionu przez rozwój górnictwa. Złóż kopalin nie można wywieźć z kraju, można je jedynie eksploatować za zgodą państwa suwerena. Dominium państwa to bowiem własność najważniejszych typów złóż kopalin. Państwo nie przestaje nigdy być właścicielem złoża, zezwala jedynie przedsiębiorcy górniczemu na zagospodarowanie złóż i wydobycie kopaliny (z tego tytułu inwestor świadczy na rzecz państwa i gminy określone obciążenia finansowe). Zwiększenie zakresu i skali działań poszukiwawczych oraz poszukiwawczo-rozpoznawczych w Polsce, a następnie realizacja projektów górniczych powinny być celem strategii państwa.

5. Coraz głębsza przeróbka kopalin, pozyskiwanie nowych grup surowców mineralnych stworzyć może gospodarce nowe impulsy rozwojowe pozwalające odejść od gospodarki surowcowej starego typu na rzecz nowoczesnej inżynierii surowcowej.

6. Obecność międzynarodowych koncernów mineralnych w Polsce jest potrzebna i pożądana. Transponują one bowiem do naszego kraju technologie i know how oraz ład korporacyjny określany mianem corporate governance. Dotyczy to także wprowadzania na polski rynek standardów międzynarodowych (JORC Code) w zakresie inżynierii finansowej projektów surowcowych (górniczych) oraz prezentacji wiarygodnych i obiektywnych wyliczeń zasobów złóż kopalin.

\section{LITERATURA}

Balvanera i in. 2006 - Balvanera, P., Pfisterer, A.B., Buchmann, N., He, J.S., Nakashizuka, T., Raffaelli, D i Schmid, B., 2006. Quantifying the evidence for biodiversity effects on ecosystem functioning and services. Ecology Letters 9, s. 1146-1156.

Behrens, W. i Hawranek, P.M. 1993. Poradnik przygotowania przemysłowych studiów feasibility - UNIDO. Wydanie II rozszerzone i uzupełnione, Warszawa, $323 \mathrm{~s}$.

Berry, M. 2009. Better decision-making from mine to market by better assessment of geological uncertainty. Proceedings from Project Evaluation Conference 2009. (The Australian Institute Mining and Metallurgy, Melbourne.)

Beniscelli, J., Carrasco, P., Dowd, P., Ferguson, G. i Talcanaza, E. 2000. Estimation of resources and conversion to reserves. Protocols for the assessment, reduction and management of risk. Proceedings MassMin 2000. The Australian Institute Mining and Metallurgy, Brisbane.

Bullock, R.L. 2011a. Accuracy of feasibility study evaluations would improve accountability. Mining Engineering 63 (4), s. 78-85.

Bullock, R.L. 2011b. Mineral property feasibility studies. In SME Mining Handbook, 3rd ed., vol. 1. Edited by P. Darling. Littleton, CO: SME.

CSA, 2011. Canadian Securities Administrators (CSA). National Instrument 43-101. [Online] Dostępne w: www.cim.org/standards [Dostęp: 10.07.2015]. 
Cloquell-Ballester i in. 2006 - Cloquell-Ballester, V. A., Cloquell-Ballester, V.A., Monterde-Diaz, R. i Santamarina-Siurana, M.C. 2006. Indicators validation for the improvement of environmental and social impact quantitative assessment. Environmental Impact Assessment Review 26(1), s. 79-105.

Chapman, C. i Ward, S. 2004. Why risk efficiency is a key aspect of best practice projects. International Journal of Project Management 22, s. 619-632.

Costanza i in. 1997 - Costanza, R., D’Arge, R., De Groot, R., Farberk, S., Grasso, M., Bruce Hannon, B., Limburg, K, Naeem, S., O’Neill, R.V., Paruelo, J., Raskin, R.G., Suttonkk, P. i van den Belt, M. 1997. The value of the world's ecosystem services and natural capital. Nature 387, s. 253-260.

De Groot i in. 2002 - De Groot, R.S., Wilson, M.A. i Boumans, R.M.J. 2002. A typology for the classification, description and valuation of ecosystem functions, goods, and services. Ecological Economics 41, s. 393-408.

Equator Principles, 2013. The Equator principles III. [Online] Dostępne w: www.equator-principles.com/index.php/about-theequator-principles [Dostęp: 10.07.2015].

IFC, 2012. Performance standards on environmental and social sustainability. Performance standards and guidance notes - 2012 edition. [Online] Dostępne w: http://www.ifc.org [Dostęp: 10.07.2015]..

JORC Code, 2012. Joint Ore Reserves Committee (2012 edition). The JORC code and guidelines. Australasian code for reporting of exploration results, mineral resources and ore reserves prepared by The Australasian Institute of Mining and Metallurgy (AusIMM), Australian Institute of Geoscientists and Minerals Council of Australia. [Online] Dostępne w: www.jorc.org [Dostęp: 10.07.2015].

Kaczmarek, T.T. 2006. Ryzyko i zarządzanie ryzykiem. Ujęcie interdyscyplinarne, Difin, Warszawa, s. 98-103.

KHW 2014. Audyt zasobów węgla kamiennego złóż kopalń KHW S.A. w oparciu o założenia metody „The JORC Code 2012”. Competent Person K. Szamałek (materiały niepublikowane).

Kremen, C. 2005. Managing ecosystem services: what do we need to know about their ecology? Ecology Letters 8 , s. $468-479$.

Mineral expert's report, 2012. Mineral expert's report on exploration results and inferred resources of nickel laterite deposit in Halmahera Island within exploration mining business license (IUP). Halmahera Resources Perkasa Ltd., Competent person K. Szamałek.

Mucha i in. 2007 - Mucha, J. (red), Nieć, M., Wasilewska, M., Sobczyk, E.J. i Saługa, P. 2007. Dokładność szacowania zasobów węgla kamiennego, jako element oceny ryzyka inwestycyjnego. Monografia, Wyd. AWK GEO, Kraków, $119 \mathrm{~s}$.

Nelson, M.G. 2011. Mine economics, management and law. [W:] SME Mining Handbook, 3rd ed., Vol. 1. Edited by P. Darling. Littleton, CO: SME.

Nieć, M. (red.). 2002. Zasady dokumentowania złóż kopalin stałych. Ministerstwo Środowiska Departament Geologii i Koncesji Geologicznych, Komisja Zasobów Kopalin, Warszawa, $40 \mathrm{~s}$.

Nieć, M. 2009. Polska i międzynarodowa ramowa klasyfikacja zasobów (UNCF) złóż kopalin stałych i węglowodorów - podobieństwa i różnice. Górnictwo Odkrywkowe R. L, nr 2-3, s. 50-57.

Nieć i in. 2014 - Nieć, M., Galos, K. i Szamałek, K. 2014. Main challenges of mineral resources policy of Poland. Resources Policy 42, s. 93-103.

Noakes, M. i Lanz, T. (editors). 1993. Cost estimation handbook for the Australian mining industry-monograph 20. The Australian Institute of Mining and Metallurgy.

Park, H.M. i Nelson, M.G. 2013. Mining project evaluation process for investment decisions: Risk variables in mining projects - part one. Mining Engineering 65(10), s. 18-18.

PolVal - Kodeks Wyceny Złóż Kopalin. [Online] Dostępne w: www.polval.pl [Dostęp: 10.07.2015]

Prawo ochrony środowiska, 2008. Ustawa z dnia 27 kwietnia 2001 r. Prawo ochrony środowiska (tekst jedn. z 2008 r. $\mathrm{Nr} 25$, poz. 150 z późn. zm.).

Saługa, P. 2009. Ocena ekonomiczna projektów i analiza ryzyka w górnictwie. Studia, Rozprawy, Monografie 152 Wyd. IGSMiE PAN, Kraków, $278 \mathrm{~s}$.

Scott, B.C. i Whateley, M.K.G. 2006. Project evaluation. [W:] Introduction to mineral exploration, 2nd ed. Edited by C.J. Moon. Massachusetts: Blackwell Publishing.

Solon, J. 2008. Koncepcja „Ecosystem services” i jej zastosowania w badaniach ekologiczno-krajobrazowych. [W]: T.J. Chmielewski (red.) Struktura i funkcjonowanie systemów krajobrazowych: meta-analizy, modele, teorie i ich zastosowania. Problemy Ekologii Krajobrazu 21, s. 25-44. 
Szamałek, K. 2007. Podstawy geologii gospodarczej i gospodarki surowcami mineralnymi. PWN Warszawa, 265 s. Uberman, R. i Galos, K. 2013. Aktualne problemy wyceny złóż kopalin skalnych. Prace Naukowe Instytutu Górnictwa Politechniki Wrocławskiej 136; Studia i Materiaty 43, s. 233-243.

Ustawa 2001. Ustawa z dnia 27 kwietnia 2001 r. prawo ochrony środowiska. Dz.U. z 2013 poz. 1232.

Ustawa 2008. Ustawa z dnia 3 października 2008 r. o udostępnianiu informacji o środowisku i jego ochronie, udziale społeczeństwa w ochronie środowiska oraz o ocenach oddziaływania na środowisko (Dz.U. z 2008 r. Nr 199, poz. 1227 z późn. zm.)

Vanclay, F. 2003. International principles for social impact assessment. Impact Assessment and Project Appraisal 21(1), s. 5-12.

Vanclay, F. i Bronstein, D.A. 1995. Environmental and social impact assessment. John Wiley \& Sons, $325 \mathrm{~s}$.

Vose, D. 2008. Risk analysis - a quantitative guide, 3rd ed. London, United Kingdom: John Wiley and Sons, s. $45-65$.

Whittle i in. 2007 - Whittle, G., Stange, W. i Hanson, N. 2007. Optimising project value and robustness. Project Evaluation Conference Melbourne, Vic, 19-20 June 2007.

Wierchowiec i in. 2013 - Wierchowiec, J., Gmura, D., Starzec, K., Szotek, A. i Schnabel, W. 2013. Technical report on hard coal and coalbed methane resources in the Babice-Polanka and Wola-Oświęcim concessions. Geokrak, $33 \mathrm{~s}$

Wirth, H. 2011. Wieloczynnikowa wycena złóż i ich zasobów na przykładzie przemysłu metali nieżelaznych. Studia, Rozprawy, Monografie 171. IGSMiE PAN Kraków, 208 s.

http://eurogeologists.eu

\section{ZNACZENIE I ROLA STANDARDU JORC JAKO PODSTAWY BANKOWEGO STUDIUM} WYKONALNOŚCI PROJEKTÓW GÓRNICZYCH DLA OCENY RENTOWNOŚCI PROJEKTU

\section{Słowa kluczowe}

projekt górniczy, standard JORC, bankowe studium wykonalności, rentowność projektu

\section{Streszczenie}

Wymagania stawiane przez międzynarodowe instytucje finansowe w zakresie raportowania wyników prac geologicznych, klasyfikacji zasobów kopalin oraz oceny rentowności projektów górniczych dla potrzeb ich finansowania wymuszają w tym zakresie konieczność stosowania jednolitych standardów. Podstawowym celem tej standaryzacji jest umożliwienie porównania wartości ekonomicznej zasobów kopaliny według jednolitych zasad i traktowania tych zasobów jako składnika aktywów przedsiębiorstwa górniczego. Potrzeba takiej standaryzacji pojawia się również w Polsce. Obecnie na świecie najczęściej jest stosowany australijski system raportowania wyników rozpoznania złoża oraz oceny jego zasobów znany pod nazwą JORC Code.

Złożoność projektów górniczych (surowcowych) oraz wielostronne czynniki ryzyka związane $\mathrm{z}$ ich oceną i wdrożeniem wymuszają w fazie przedinwestycyjnej projektu konieczność przygotowania optymalnej koncepcji zagospodarowania złoża - Bankowego Studium Wykonalności (BSW). Celem BSW jest optymalizacja decyzji inwestora o najmniejszym ryzyku w świetle posiadanej wiedzy na temat technicznej i finansowej wykonalności danego projektu górniczego. BSW jest zatem narzędziem (instrumentem) wykorzystywanym do podjęcia obiektywnych (najlepiej trafnych) i obarczonych możliwie niskim ryzykiem decyzji inwestycyjnych. Kompleksowa ocena rentowności 
projektu górniczego z uwzględnieniem wszelkich czynników geologiczno-górniczych, technicznych, ekonomicznych, marketingowych, prawnych, środowiskowych oraz istotnych względów społecznych i administracyjnych podjęta na etapie koncepcyjnym (studium), pozwala na ograniczenie ryzyka w fazie wykonania projektu (budowa zakładu górniczego). Tym samym BSW jest instrumentem oceny rentowności projektu oraz efektywnym narzędziem minimalizacji ryzyka przyjęcia do realizacji projektu, który jest niewykonalny albo nieracjonalny.

\section{THE MEANING AND ROLE OF THE BANKABLE FEASIBILITY STUDY (BFS) AS A BASIS FOR JORC MINING PROJECTS' FEASIBILITY ASSESSMENT AND PROFITABILITY EVALUATION}

\section{Keywords}

mining project, standard JORC, bankable feasibility study, mining project profitability

\section{Abstract}

International financial institutions require uniform standards for geological exploration reports, classification of mineral reserves as well as profitability assessments of mining projects. Such standardization is motivated by the necessity to compare the economic value of mineral deposits (treated as part of a mining company's assets) using uniform rules. The need for such standardization also exists in Poland. Presently, the Australian JORC Code is the most often used standard for mineral reserve identification and assessment.

Mining projects are very complex and risky, therefore it is necessary to prepare a special report called a bankable feasibility study (BFS) in the pre-investment stage to ensure the selection of the optimal plan for mineral deposit development. The role of the BFS is to optimize investor decisions and to select a plan characterized by minimal risk, taking into account the knowledge about technical and financial feasibility of the mining project. During the comprehensive profitability analysis of mining projects, it is necessary to consider the following aspects: mining, geological, technical, economical, marketing, legal, environmental as well as social and administrative. Comprehensive analysis in the concept stage minimalizes the risk in the development stage (mine construction). Growing activity by international investors in Poland in the area of geological exploration and mining project development is tied to introducing the corporate governance and know-how, including the use of the JORC code. 